\title{
Vascular Endothelial Growth Factor-C Expression in Servical Squamous Cell Carcinoma of Patients with Neoadjuvant Chemotherapy
}

\author{
Uswatun Khasanah Kartikasari, Heru Priyanto, Supriyadi Hari Respati
}

Department of Obstetrics and Gynecology, Faculty of Medicine, Universitas Sebelas Maret/ Dr. Moewardi Hospital, Surakarta

\begin{abstract}
Background: Uterine cervical carcinoma is the most gynecological malignancy in women worldwide. The most common type of cervical carcinoma histology is squamous cell carcinoma and has a better prognosis than adenocarcinoma. Neoadjuvant chemotherapy is the management of early-stage cervical carcinoma before radical hysterectomy is performed. In addition to clinicalpathological factors, biomolecular markers are now being developed and used as parameters for evaluating chemotherapy responses. Vascular Endothelial Growth Factor-C is a VEGF derivative that plays a role in the process of vasculogenesis, limphangiogenesis, and the formation of new lymphatic channels which play an important role in metastasis. This study aimed to examine the effect of Paxus-Carboplatin chemotherapy in decreasing VEGF-C in squamous cell cervical carcinoma tissue.
\end{abstract}

Subjects and Method: This was a quasi experiment study conducted at Department of Obstetrics and Gynecology and Pathology Anatomy Laboratory of Dr. Moewardi Hospital/ Faculty of Medicine, Universitas Sebelas Maret. 25 tissue samples of squamous cell stage IB2-IIA2 cervical carcinoma immunohistochemistry VEGF-C expression was carried out before and after PaxusCarboplatin chemotherapy was given. The data were analyzed by Wilcoxon test.

Results: VEGF-C expression in squamous cell cervical carcinoma tissue after chemotherapy was lower $($ mean $=4.20)$ than before chemotherapy $($ mean $=6.16)$ and it was statistically significant $(\mathrm{p}<0.001)$.

Conclusion: Neoadjuvant chemotherapy decreases VEGF-C in squamous cell cervical carcinoma tissue.

\section{Correspondence:}

Uswatun Khasanah Kartikasari. Department of Obstetrics and Gynecology, Faculty of Medicine, Universitas Sebelas Maret/ Dr. Moewardi Hospital, Surakarta. Mobile: 081391444425. Email: uswatunkk@gmail.com

\section{BACKGROUND}

Uterine cervical carcinoma is the fourth largest cancer and gynecological cancer in women worldwide with a mortality mortality to incidence of $55 \%$ (International Agency for Research on Cancer, 2012). In Indonesia, cervical carcinoma is the most common malignancy in women $(17.8 \%$ ) with 40,000 cases of cervical carcinoma occurring annually. According to the Indonesian Ministry of Health, currently the number of women with new cervical carcinoma ranges from 90-100 cases per
100,000 population (Ministry of Health, 2013). The most common histological types of cervical carcinoma were squamous cell carcinoma (75.9\%) followed by adenocarcinoma (11.4\%), adenosquamose, neuroendocrine, and other types (12.7\%) (Lindstr, 2010). Patients with squamous cell cervical carcinoma have a better prognosis than adenocarcinoma (Wada et al., 2014). Management of early-stage cervical carcinoma is by giving neoadjuvant chemotherapy before radical hysterectomy surgery, especially in patients with lesions more than $4 \mathrm{~cm}$ or 
called bulky lesion (RI Ministry of Health, 2013). Assessment of the chemotherapy response has been carried out by seeing a large decrease in cervical lesions. However, currently biomolecular markers are also being developed and used as parameters for evaluating chemotherapy responses because they are expected to increase the success of therapy in patients with cervical carcinoma in early stage uterias (Nakamura et al., 2014).

Recent studies have shown the importance of tumor angiogenesis as a key factor affecting patient survival and the prognosis of several gynecological malignant tumors (Mandic, Knezevic, and Ivkovic, 2014). Increased levels of Vascular Endothelial Growth Factor (VEGF) will stimulate angio-genesis activity which is part of the metastatic process (Agustiyansah, 2014). Vascular Endothelial Growth Factor-C (VEGF-C) is one of the VEGF derivatives that plays a role in vasculogenesis and limphangiogenesis. Lymph node metastasis is the main metastatic pathway of cancer cells, so lymphangiogenesis is an important factor in the metastatic process (Chang et al., 2012; Nakamura et al., 2014). (Franc et al., 2015) examined the expression of VEGF-C in cervical carcinoma tissue which results in increased VEGF-C expression in advanced stage cervical carcinoma. This shows the importance of VEGF-C as a proangiogenic factor in the process of cervical carcinoma neoangiogenesis.

VEGF-C expression is triggered by cell hypoxic conditions in large (bulky) cervical carcinoma lesions, leading to the emergence of HIF-1 $\alpha$ then increasing regulation of VEGF gene expression levels and also increasing transcriptional activity in the VEGF signal transduction pathway (Zhang et al. , 2016).

Study by Zhang et al. (2016) showed that VEGF protein expression was signifi- cantly higher in squamous cell carcinoma tissue than normal cervical tissue. In addition, high mRNA expression from HIF$1 \alpha$ and VEGF was associated with increased metastatic potential in carcinoma squamous cell cervix.

This study studied the expression of VEGF-C in the tissue of squamous cell cervical carcinoma patients after being given neoadjuvant chemotherapy. Examination of biomolecular markers as a parameter for evaluating chemotherapy responses is expected to bring improvements in the management of cervical carcinoma patients. Assessment of chemotherapy responses using biomarkers is expected to be better because it is upstream, more objective and has wider benefits.

\section{SUBJECTS AND METHOD}

\section{Study Design}

This was a quasi experiment study. The study was conducted at Department of Obstetrics and Gynecology and Anatomy Pathology Laboratory, Dr Moewardi Hospital/Faculty of Medicine, Universitas Sebelas Maret, from September 2017 to March 2018.

\section{Study Sample}

A total of 25 samples from tissue biopsy of squamous cell stage $2 \mathrm{~N} 2 \mathrm{~A}$ cervical carcinoma patients performed immunohistochemical VEGF-C expression before and after Paxus-Carboplatin chemotherapy was given.

\section{Study Variables}

The dependent variable was VEGF-C tissue expression. The independent variable was neoadjuvant chemotherapy.

\section{Data Analysis}

The data analysis was done using the Wilcoxon Test. 
Indonesian Journal of Medicine (2019), 4(1): 40-45

https://doi.org/10.26911/theijmed.2019.04.01.07

\section{RESULTS}

The majority of the study subjects were 4060 years old $(72.0 \%)$, elementary school education (52.0\%), null parity (64.0\%), stage IIA2 cervical cancer sufferers (88.0\%) (Table 1).

The mean results of cervical tissue VEGF-C expression after administration of Table 1. Sample Characteristics

\begin{tabular}{llcc}
\hline \multicolumn{1}{c}{ Characteristics } & \multicolumn{1}{c}{ Category } & Frequency & Percentage \\
\hline \multirow{3}{*}{ Age } & < 40 years old & 4 & $16.0 \%$ \\
& 40-60 years old & 18 & $72.0 \%$ \\
& > 60 years old & 3 & $12.0 \%$ \\
& Not Graduated & - & - \\
\multirow{5}{*}{ Education } & Elementary school & 13 & $52.0 \%$ \\
& Junior high school & 3 & $12.0 \%$ \\
& Senior high school & 7 & $28.0 \%$ \\
Parity & Diploma & - & - \\
& Bachelor & 2 & $8.0 \%$ \\
Stadium & O - 2 & 16 & $64.0 \%$ \\
& $>2$ to 4 & 8 & $32.0 \%$ \\
& $>4$ & 1 & $4.0 \%$ \\
& I B2 & 3 & $12.0 \%$ \\
& II A2 & 22 & $88.0 \%$ \\
\hline
\end{tabular}

neoadjuvant chemotherapy were lower $($ mean $=4.20)$ than before $($ mean $=6.16)$ with $\mathrm{p}<0.001$. It showed that there was a very significant difference in cervical tissue VEGF-C expression before and after the administration of neoadjuvant chemotherapy.

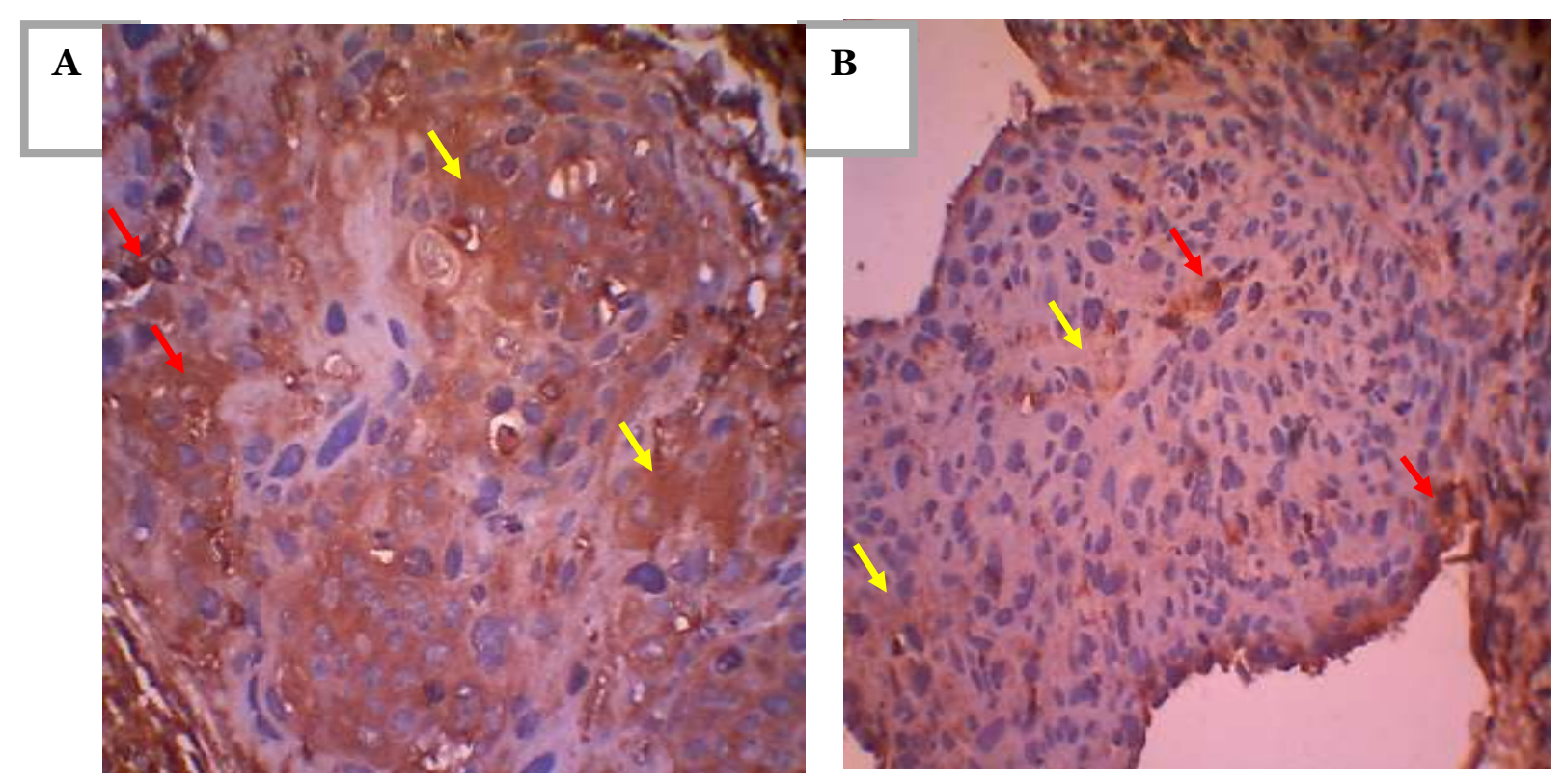

Figure 1.Microfotographic description of VEGF-C tissue expression

A. Before neoadjuvant chemotherapy. B. After neoadjuvant chemotherapy.

Description: Red arrows show VEGF-C expression in the cytoplasm, and yellow arrows show intercellular VEGF-C expression. 
Table 2. The mean of cervical tissue VEGF-C expression before and after neoadjuvant chemotherapy

\begin{tabular}{|c|c|c|c|}
\hline Time & $\mathbf{N}$ & $\begin{array}{c}\text { The mean expression } \\
\text { of VEGF-C tissue }\end{array}$ & $\mathbf{p}$ \\
\hline Before & 25 & 6.16 & $<0.001$ \\
\hline After & 25 & 4.20 & \\
\hline
\end{tabular}

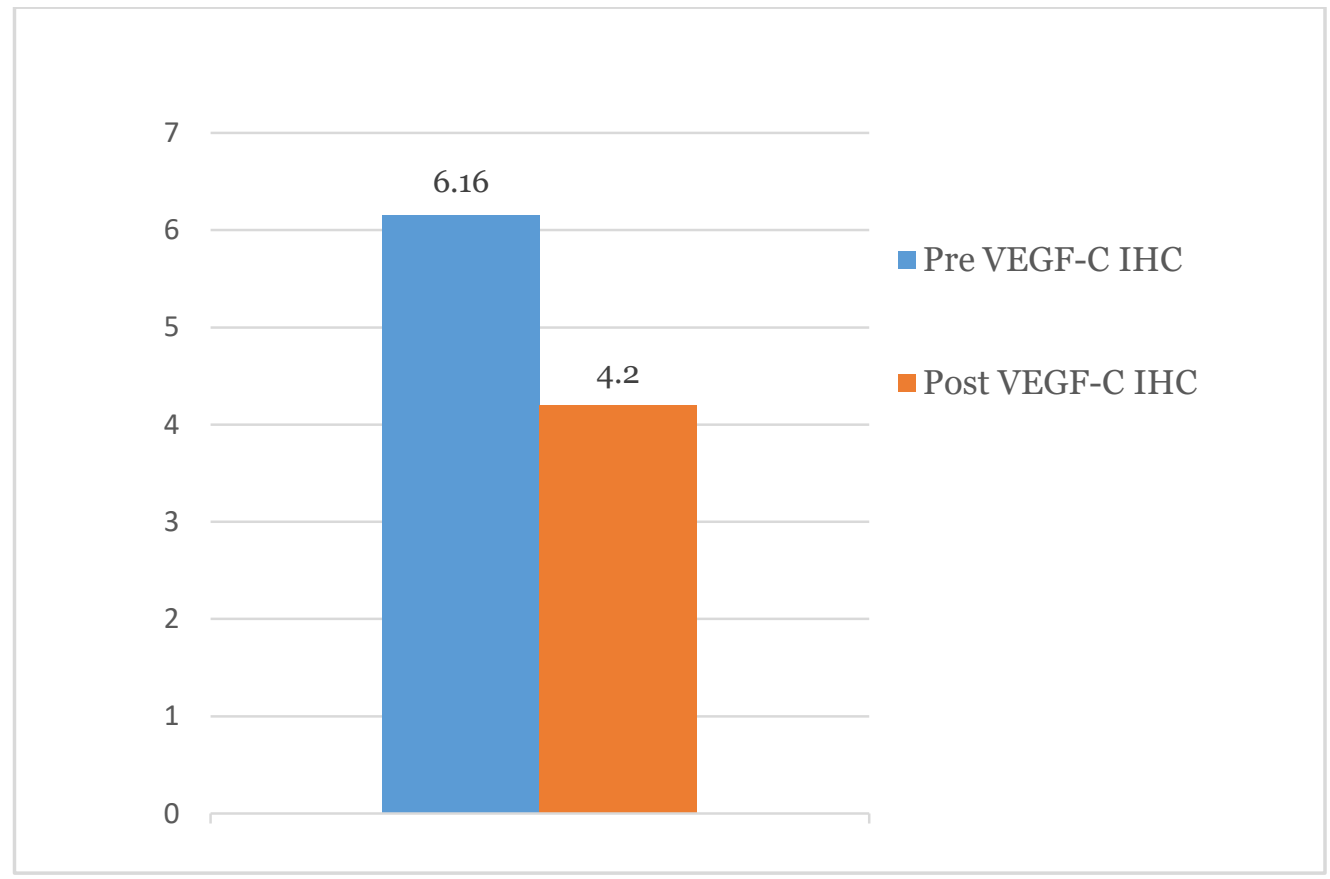

Figure 2.The mean expression of VEGF-C in the tissue

\section{DISCUSSION}

In this study most of the research subjects was $40-60$ years old (72\%). This was in accordance with epidemiological research data which stated that the highest age group of cervical cancer patients was 45-54 years old (Aziz, 2009). Regarding the prevalence of HPV infection which increased with increasing age (Powell et al., 2011).

The educational background of the study subjects was mostly elementary school (52.0\%) and the parity was mostly between 0-2 (64.0\%). A low educational background was a risk factor for cervical carcinoma. Besides sexual activity at a young age, having sex with multipartners, smoking, low socio-economic conditions, the use of birth control pills, sexually transmitted diseases, and impaired immunity were the risk factors for cervical carcinoma. Stage IIA2 sufferers were more numerous than stadium IB2 (88\%). This was consistent with the data that most cases (62-82\%) came at an advanced stage in developing countries, such as Indonesia (Aziz, 2009).

Neoadjuvant chemotherapy was given with the aim of reducing the size of lesions in the cervix, so that it can reduce angiogenesis in tumor cells, then can reduce the expression of HIF-1a, followed by a decrease in transcription of the VEGF-C gene (Osman, 2014). As a result, the synthesis of VEGF-C m-RNA has also decreased, so it was expected that the production of VEGF-C proteins expressed in tissues also decreased (Mandic, Knezevic, and Ivkovic 2014; Morfoisse et al., 2014). In addition, neoadjuvan chemo- 
therapy can also affect the process of lymphangiogenesis and angiogenesis and kill cancer cells, both locally and metastasized, therefore, the expression of VEGF$\mathrm{C}$ in cervical tissue was expected to decrease after the chemotherapy was given (Wang, Li, and Zhao, 2016).

Multivariate analysis revealed that VEGF-C expression was an independent factor affecting lymph node metastasis (Nakaamura et al., 2014). Metastasis in lymph nodes was one of the prognosis factors or a free predictor of survival rates. Patients without metastasis in lymph nodes have a 5-year survival rate of $91 \%$, while patients with lymph node metastases have an average of $67 \%$. In patients with squamous cell carcinoma of the stage IB-IIIB VEGF-C expression was higher than normal cervical tissue, and the increase in expression was directly proportional to the higher clinical stage (Franc et al., 2015).

In this study, there were several limitations. The researchers did not examine external factors that could affect the expression of VEGF-C in cervical tissue squamous cell carcinoma. In addition, the chemotherapy given in the study was 3 series, further study is needed especially for advanced cervical carcinoma of the uterus given chemotherapy to 6 series. This study used an immunohistochemical score that was semi quantitative to assess the response to chemotherapy. Other quantitative tests such as PCR examination will give more accurate results.

Based on the results of the study, it can be concluded that the expression of VEGF-C in squamous cell cervical carcinoma tissue decreased significantly in patients given neoadjuvant chemotherapy, so that VEGF-C tissue expression can be used as a parameter for evaluating chemotherapy responses.

\section{REFERENCES}

Agustiyansah P (2014). VEGF-C serum level as predictor lymph node metastasis in advanced stage cervical cancer. Indonesian Journal of Cancer. 8(3). http://www.indonesianjournalofcancer.or.id/e-journal/index.php/ijoc/article/view/357.

Aziz MF (2009). Gynecological cancer in Indonesia. Journal of Gynecologic Oncology. 20(1): 8-10.

Chang YW, Yu YH, Chen JC, Su JL, Hong CC (2012). The Role of the VEGFC/VEGFRs Axis in Tumor Progression and Therapy. International Journal of Molecular Sciences. 14(1): 88-107.

Franc M, Kachel-Flis A, Michalski B, FilaDaniłow A, Mazurek U, Michalski M, Michalska A, Kuczerawy I, Skrzypulec-Plinta V (2015). Lymphangiogenesis In cervical cancer evaluated by expression of the VEGF-C gene in clinical stage IB-IIIB. Przeglad Menopauzalny. 14(2): 112-7.

International Agency for Research on Cancer (2012). Globocan 2012 Cancer Fact Sheet', International Agency for Research on Cancer, pp. 1-6.

Kementerian Kesehatan RI (2013). Panduan Penatalaksanaan Kanker Serviks. Komite Penanggulangan Kanker Nasional.

Lindstr $A(2010)$. Prognostic factors for squamous cell cervical cancer, Oncology.

Mandic A, Knezevic SU, Ivkovic TK (2014), Tissue expression of VEGF in cervical intraepithelial neoplasia and cervical cancer.Journal of B.U.ON. 19(4): 958-64.

Morfoisse F, Renaud E, Hantelys F, Prats AC, Garmy-Susini B (2014). Role of hypoxia and vascular endothelial growth factors in lymphangiogenesis. Molecular and Cellular Oncology. 1(1): 
$1-8$.

Nakamaura K, Aoki D, Umene K, Banno K, Yanokura M, Iida M, Kisu I, Tanaka $\mathrm{K}$, Nogami $\mathrm{Y}$, Adachi $\mathrm{M}$, Iwata $\mathrm{T}$, Masuda K (2014). Candidate biomarkers for cervical cancer treatment: Potential for clinical practice (Review). Molecular and Clinical Oncology. 2(5): 647-55.

Osman M (2014).The role of neoadjuvant chemotherapy in management of locally advanced cancer cervix: A systemic review. Oncology Reviews. 8(2).

Powell NG, Hibbitts SJ, Boyde AM, Newcombe RG, Tristram AJ, Fiander AN (2011). The risk of cervical cancer associated with specific types of human papillomavirus: A case-control study in a UK population. International Journal of Cancer. 128(7): 1676-
82.

Wada T, Fukuda T, Kawanishi M, Hashiguchi Y, Sumi T, Yamauchi M, Ichimura T, Imai K, Yasui T (2014).Comparison of outcomes between squamous cell carcinoma and adenocarcinoma in patients with surgically treated stage I-II cervical cancer. Molecular and Clinical Oncology. 2(4): 518-24.

Wang H, Li S, Zhao H (2016). Effect of different preoperative neoadjuvant chemotherapy on cervical cancer angiogenesis and cell proliferation. 22(20): $115^{-8 .}$

Zhang L, Liu C, Hu J, Xu C, Chen Y, Chen Q (2016). Expression of HIF-2 $\alpha$ and VEGF in cervical squamous cell carcinoma and its clinical significance. BioMed Research International. 